\title{
ON THE 1983 DROUGHT IN NORTH-EAST BRAZIL
}

\author{
V. BRahmananda RaO, P. Satyamurty and josé iVAldo. B. DE brito* \\ Instituto de Pesquisas Espaciais-INPE, Conselho Nacional de Desenvolvimento Cientifico è Technológico-CNPq, Sāo José dos \\ Campos, S. P. Brazil
}

Received 20 February 1985

Revised 30 May 1985

\begin{abstract}
Examination of the rainfall data for north-east (NE) Brazil showed that the drought of 1983 was extensive. In the interior dry region, rainfall during the rainy season of 1983 was less than 40 per cent of the normal. Analysis of the rainfall revealed that the drought of this year was the worst in the past 20 years. Rainfall anomalies over NE Brazil are related to the Southern Oscillation and sea surface temperature (SST) anomalies in the tropical Atlantic Ocean. Variations in the Southern Oscillation index preceded the corresponding rainfall anomalies by about 2 months. Correlation coefficient between the NE Brazil seasonal rainfall and mean monthly SST anomaly in the tropical Atlantic showed a gradual increase from January to March. However, examination of sea surface temperature anomalies in the Atlantic for the first 3 months of 1983 indicated only a weak relationship with rainfall anomalies. This suggests that for the 1983 event east-west Walker type circulation was more important than the north-south meridional circulations forced by SST anomalies in the Atlantic.
\end{abstract}

KEY wORDS Southern Oscillation-North-east Brazil 1983 drought

\section{INTRODUCTION}

North-east (NE) Brazil is characterized by large interannual variations of rainfall. During some years severe droughts lead to intensive human suffering and mass exodus. This region has an area of about a million square kilometres and is inhabited by more than 30 million people. Although the east coast recelves annually $2000 \mathrm{~mm}$ of rainfall. portions of the interior dry region receive less than $400 \mathrm{~mm}$ (Kousky and Chu, 1978). The rainy season is centred upon March, April and May with almost no precipitation during the remaining nine months (Strang, 1972).

Mechanisms offered to explain the interannual variations of rainfall over NE Brazil are many. Hastenrath and Heller (1977) showed that the strength and position of the intertropical convergence zone (ITCZ) have a profound influence on the seasonal rainfall of this region. Moura and Shukla (1981) related the interannual variations of rainfall in NE Brazil to the sea surface temperature (SST) anomaly in the Atlantic Ocean. Simultancous occurrence of warm waters in the tropical North Atlantic and cold waters in the equatorial South Allantic seems to induce a meridional circulation cell with subsidence over NE Brazil. Thus, interannual variations of rainfall in NE Brazil are related to the variations in the strength of this meridional cell. Another mechanism involves the variability of the east-west direct thermal circulation, or Walker circulation, associated with the Southern Oscillation (SO) (Kidson, 1975; Stoeckenius, 1981). Yet another explanation offered by Kousky (1979) relates the northward penetration and number of the cold fronts from the south into NE Brazil and the rainfall. This relation is a kind of teleconnection between the blocking situation in the higher southern latitudes and the weather in NE Brazil. Namiats (1972) suggested a teleconnection between the intensity of eyclonic circulation over the Newfoundland area and the rainfall intensity over NE Brazil.

\footnotetext{
* Present address: FUNCEME, Fortaleza, CE, Brazil

0196-1748/86/010043-09\$05.00

(C) 1986 by the Royal Meteorological Society
} 
The mechanisms cited above are certainly interrelated and can be divided into two broad categories. Those mechanisms which are related in a meridional direction in the Atlantic and adjoining continents and the others which are connected in the east-west direction in the equatorial latitudes. Thus, the SST anomalies in the Atlantic, the intensity of meridional circulation, the activities in the extratropical latitudes land pressure anomalies are all closely linked. On the other hand, blocking in fronts into tropical South of the Southern Hemisphere and the northward position of the Walker circulation modulated by America may be related to the intensity ho latter processes see Kousky et al. (1984).

a fairly intense drought. In the interior dry region,

During the year 1983, NE Brazil experienced a the cities required supplies even of drinking water. rainfall was only 40 per cent of the normal. Sos occurred in some other parts of the globe also. These During the years 1982-1983 rainfall extremes seem to be related to the SO (Rasmusson and Wallace, many respects (Quiroz, 1983). First indication of positi South America during the southern summer as during the southern winter rather than near the coast happened in other events. By the beginning of 1983, the SO (Quiroz, 1983). The present study analyses deviations below normal, the lowest on record since 1935 (Q) the rainfall characteristics of NE Brazil
mechanisms thought to be causing them.

\section{ANALYSIS OF 1983 PRECIPITATION}

As mentioned in the introduction, the principal rainy season for most of NE Brazil is rather short and occurs in the months of March, April and May. Figure 1 shows the normalized deviation of seasonal

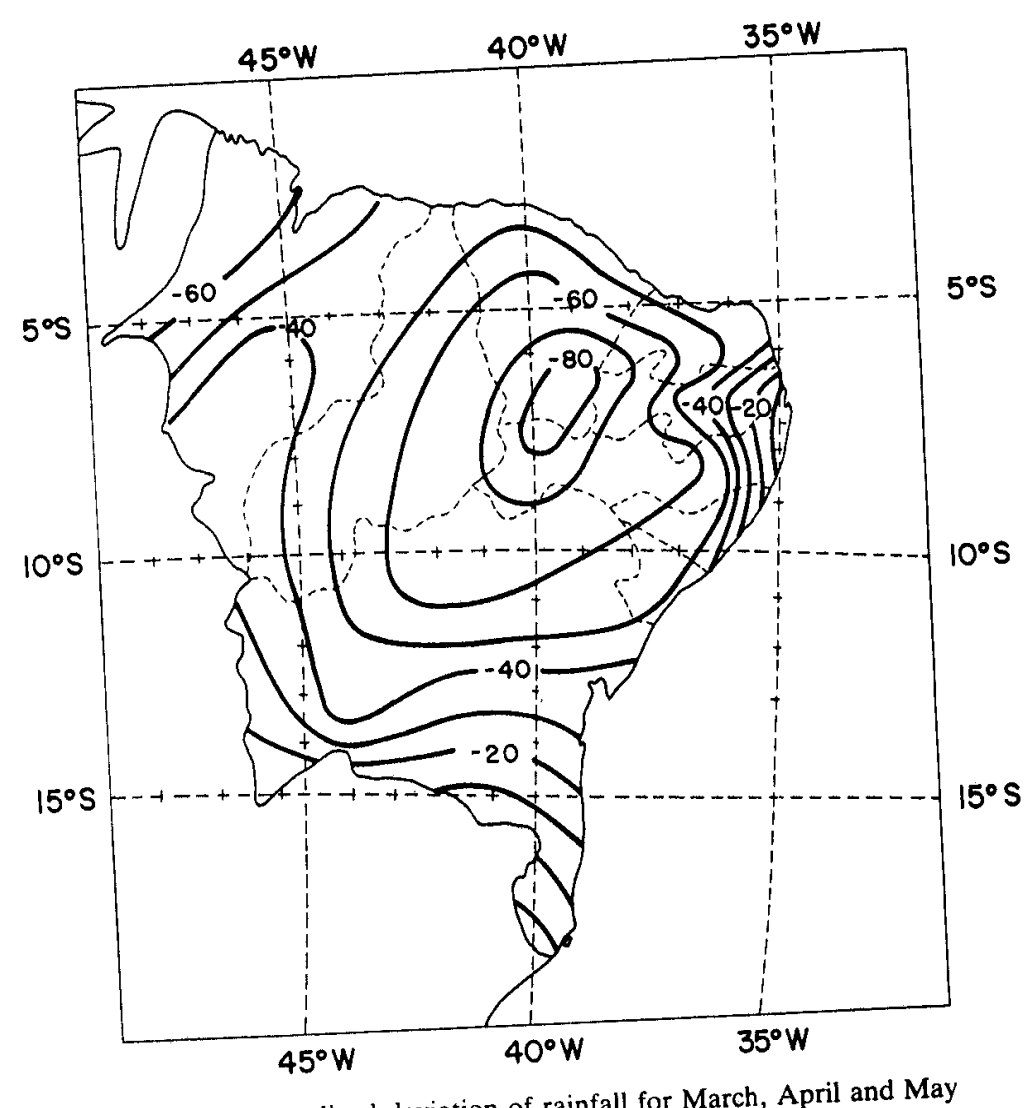

Figure 1. Normalized deviation of rainfall for March, April and May 


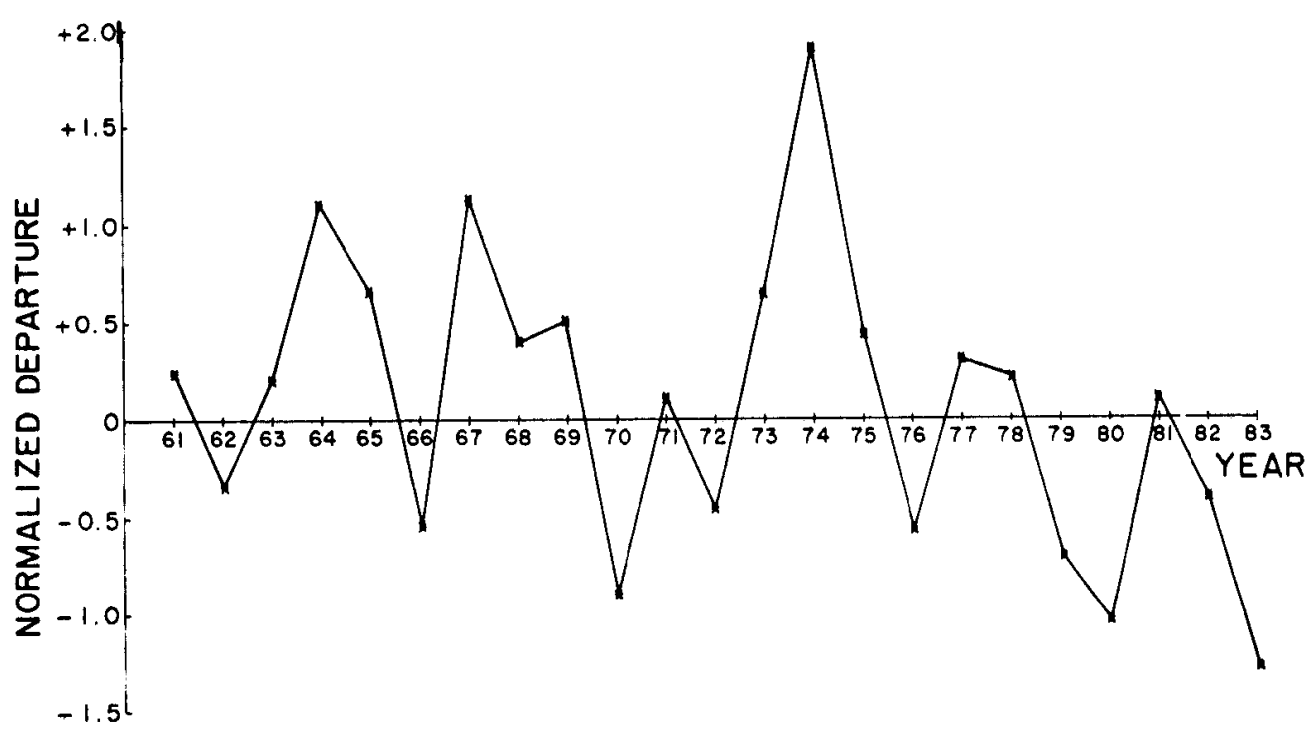

Figure 2. Normalized departure of March, April and May rainfall based on 20 stations in north-east Brazil

rainfall in NE Brazil. Normalized deviation $D_{i}$, at the $i$ th station is calculated using the formula

$$
D_{l}=\frac{P_{l}-\bar{P}}{\bar{P}} \times 100
$$

where $P_{i}$ is the precipitation for the 3 month period March, April and May of 1983, and $\bar{p}$ is the normal (average for the same 3 month period for 40 years, 1931-1970). We used rainfall data of 51 rain-gauge stations, which are uniformly distributed over NE Brazil. The rainfall data were obtained from Instituto Nacional de Meteorologia of Brazil. It can be seen from Figure 1 that most of NE Brazil experienced less than normal rainfall, with deviations as much as 80 per cent in the so-called drought polygon (see Ramos, 1975, for the definition of drought polygon). Compared to the dry year 1976 (see Figure 5 of Marques et al., 1983) the drought of 1983 seems to be more extensive.

In order to compare the intensity of 1983 drought with the rainfall anomalies of the previous years, we examined the rainfall data of 20 stations situated in northern NE Brazil (see Chu, 1983, for the location of northern NE Brazil) for the 23 year period 1961-1983. Initially means and standard deviations are determined for each station. Then the departures of individual years are expressed in terms of standard deviation, producing normalized departures. All station averages of normalized departures are shown in Figure 2. It can be seen that the 1983 drought was quite intense and the worst during the last 20 years. Also, during the last 5 years NE Brazil's interior has been under the influence of a dry spell, except for the year 1981. Even during 1981 only March rainfall was higher than normal with April and May rainfall being much below the respective normals (higher rainfall in March raised the seasonal value of 1981 slightly above normal). The normalized deviation of 1983 rainfall is $-1 \cdot 3$, as compared to -1.0 in 1980 , the second worst drought year in the last two and a half decades.

\section{CONNECTION WITH THE SOUTHERN OSCILLATION}

Southern Oscillation is the name given to a see-saw in sea-level pressure between the south-east Pacific subtropical high and the region of low pressure stretching across the Indian Ocean from Africa to Northern Australia. More than half a century ago, Sir Gilbert Walker initiated the study of the characteristics and extent of this pressure oscillation (see Rasmusson and Carpenter, 1982, for a review). The variations of SO are measured by means of indices. One such index is the surface pressure 
difference between Easter Island $\left(27^{\circ} 10^{\prime} \mathrm{S}, 109^{\circ} 26^{\prime} \mathrm{W}\right)$ and Darwin $\left(12^{\circ} 26^{\prime} \mathrm{S}, 130^{\circ} 2^{\prime} \mathrm{E}\right)$, representing the two centres of action mentioned earlier. The fluctuations of SO seem to be related in a coherent way to the pressure, temperature and rainfall over many parts of the globe. Walker himself suggested a

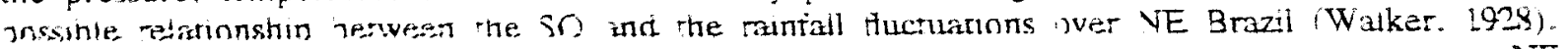
Hastenrath and Heller (1977) and Hastenrath el al. (1984) pomted oui the connection Detween NE Brazil rainfall SST along the Equador-Peru coast and the SO.

In order to verify the relationship between the SO and rainfall over NE Brazil, we correlated the SO index with rainfall over NE Brazil. We took sea level pressure at Easter Island minus Darwin sea level pressure as the SO index. Table I shows the correlation coefficients between the SO index of September to May with the rainfall of March. April and May over NE Brazil. Rainfall data for 23 years (1961-1983) of the same 20 stations mentioned earlier are used to calculate these correlation coefcients. It is seen from the Table that the highest positive correlation with precipitation occurs with a lag of two months. that is. January SO index has highest correlation with the rainfall of March, February index with the rainfall of April. and March index with the rainfall of May. All these highest correlation coefficients (marked ${ }^{*}$ in the Table) are significant at the 95 per cent level and one of them (marked ** in the Table) is significant at the 99 per cent level.

Table 1

\begin{tabular}{|c|c|c|c|}
\hline \multirow{2}{*}{$\mathrm{SO}$ index } & \multicolumn{3}{|c|}{ Rainfall over NE Brazil } \\
\hline & March & April & May \\
\hline Sepremiter & (b) & (1).26 & (1). 15 \\
\hline October & 0.29 & $-0 \cdot 1$ & $-0 \cdot 19$ \\
\hline November & 0.26 & 0.28 & 0.27 \\
\hline December & 0.21 & 0.23 & $0 \cdot 14$ \\
\hline January & $0.47^{*}$ & 0.28 & $0 \cdot 22$ \\
\hline February & 0.27 & $0.56^{* *}$ & 0.16 \\
\hline March & 0.26 & $0.44^{*}$ & $0.46^{*}$ \\
\hline April & - & 0.33 & $0 \cdot 14$ \\
\hline May & - & - & $-0 \cdot 15$ \\
\hline
\end{tabular}

* significant at the 95 per cent level

** significant at the 99 per cent level

The correlation coefficient between the SO index for the 3 month period December, January and February and the rainfall of March, April and May is 0.47 (significant at the 95 per cent level). The correlation coefficient between the SO index of January, February and March and the rainfall of March, April and May is 0.56 (significant at the 99 per cent level).

These correlations suggest that when the SO index is positive (higher than normal pressure over Easter Island and lower than normal pressure over Darwin), the rainfall over NE Brazil tends to be higher than normal. Rainfall tends to be lower than normal when SO index is negative. It is known that negative SO index is associated with oceanic warming along the Equador-Peru coast, known as El Niño. Thus El Niño years tend to coincide with drought years, a situation noted by Caviedes (1973) and Hastenrath and Heller (1977).

\section{CONNECTION WITH ATLANTIC SST ANOMALIES}

The link between atmosphere and ocean remains uncertain. The SST departures owe their origin somehow to anomalous surface wind field (and associated departures in the wind stress pattern). Once the SST anomalies are created, they are bound to affect the atmosphere, and the study of the response of the atmosphere to these anomalies is interesting. As a basis for their theoretical and numerical model studies, Moura and Shukla (1981) calculated linear correlations between the average seasonal rainfall for Fortaleza and Quixeramobim and the March SST anomaly for the tropical Atlantic. The isopleths of 


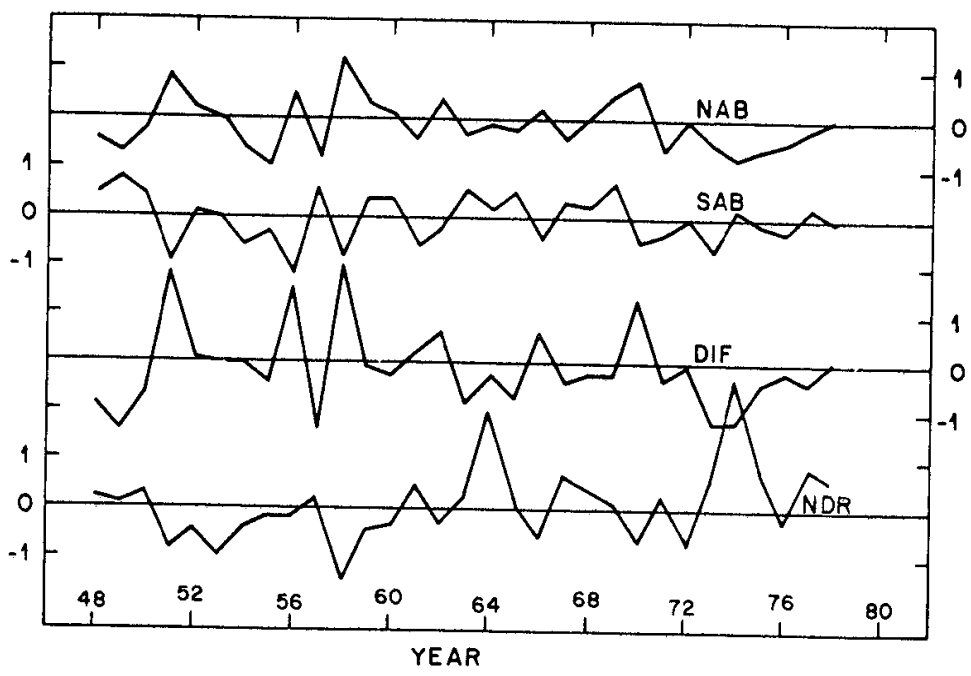

Figure 3. March SST anomalies in the North Atlantic box (NAB), the South Atlantic box (SAB) and their difference (DIF) in ${ }^{\circ} \mathrm{C}$. NDR is the normalized deviation of rainfall over NE Brazil

correlation coefficient show a highly significant maximum in the mid South Atlantic and a fairly significant minimum in the North Atlantic. It is however desirable to see how well the rainfall of the whole dry region is correlated with SST. For this purpose we calculated linear correlations between the normalized deviations of yearly rainfall over NE Brazil and the SST anomalies in the two $10^{\circ}$ latitude-longitude boxes around the maximum and minimum obtained by Moura and Shukla. The boxes are respectively bounded by $10^{\circ} \mathrm{S}, 20^{\circ} \mathrm{S} ; 0^{\circ}, 10^{\circ} \mathrm{W}$ denoted by SAB (for South Atlantic box) and $10^{\circ} \mathrm{N}, 20^{\circ} \mathrm{N} ; 40^{\circ} \mathrm{W}, 50^{\circ} \mathrm{W}$ denoted $\mathrm{NAB}$ (for North Atlantic box). Figure 3 shows a graph of March SST anomalies in $\mathrm{NAB}$ and $\mathrm{SAB}$, their difference and the normalized deviation of yearly rainfall as given by Hastenrath et al. (1984) for 31 years starting from 1948. Rainfall data are averages for 30 stations in northern NE Brazil and are for the twelve month period, October-September. The SST data from 1948 to 1972 are taken from Bunker (1976) and from 1973 to 1978 are taken from Servain et al. (1984). We may note that a great percentage of the yearly rainfall over NE Brazil falls in March, April and May and therefore the annual rainfall represents seasonal rainfall quite well and vice-versa.

The correlation coefficients obtained between rainfall and SST anomalies and their difference are given in Table II. Correlations between the rainfall and SST anomaly in NAB are all negative and between the rainfall and SST anomaly in SAB are positive for all months from October to April. This indicates that lower seasonal rainfall over NE Brazil is associated with higher SST anomalies in NAB and lower SST anomalies in SAB. Seasonal rainfall over NE Brazil is highly significantly negatively

Table II

\begin{tabular}{lllll}
\hline Month & $\begin{array}{c}\text { SSTN vs } \\
\text { NDR }\end{array}$ & $\begin{array}{c}\text { SSTS vs } \\
\text { NDR }\end{array}$ & $\begin{array}{c}\text { SSTD vs } \\
\text { NDR }\end{array}$ & $\begin{array}{c}\text { SSTN vs } \\
\text { SSTS }\end{array}$ \\
\hline October & -0.06 & +0.24 & -0.21 & -0.11 \\
November & -0.07 & $+0.47^{* *}$ & $-0.40^{* *}$ & -0.11 \\
December & -0.22 & $+0.39^{* *}$ & $-0.43^{* *}$ & -0.10 \\
January & -0.07 & $+0.32^{* *}$ & -0.25 & -0.21 \\
February & $-0.44^{* *}$ & +0.26 & $-0.45^{* *}$ & -0.19 \\
March & $-0.63^{* *}$ & $+0.31^{*}$ & $-0.58^{* *}$ & $-0.33^{*}$ \\
April & $-0.49^{* *}$ & $+0.33^{*}$ & $-0.51^{* *}$ & -0.10 \\
\hline
\end{tabular}

* significant at the 95 per cent level

** significant at the 99 per cent level 


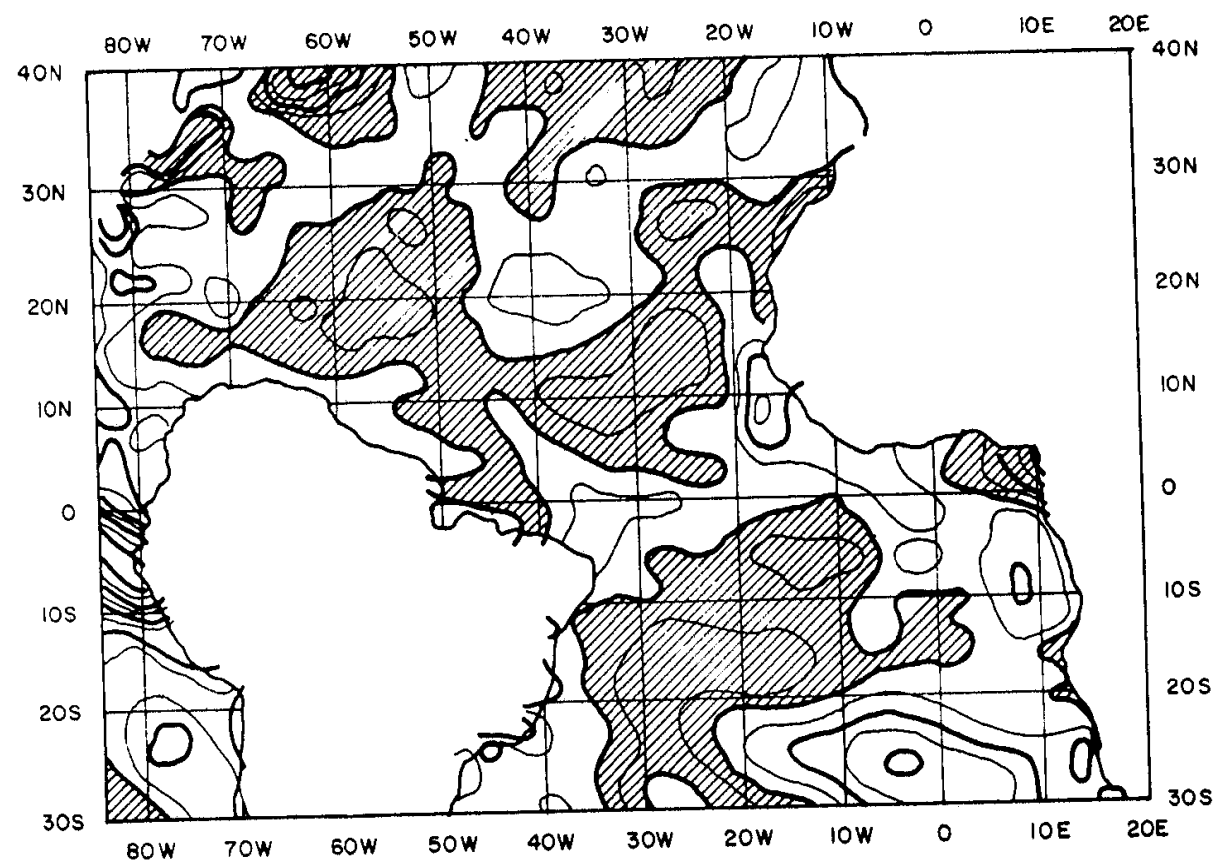

Figure 4. January $1983 \mathrm{SST}$ anomalies in ${ }^{\circ} \mathrm{C}$. Hatched areas indicate negative values. Isolines are drawn at intervals of $0.5^{\circ} \mathrm{C}$

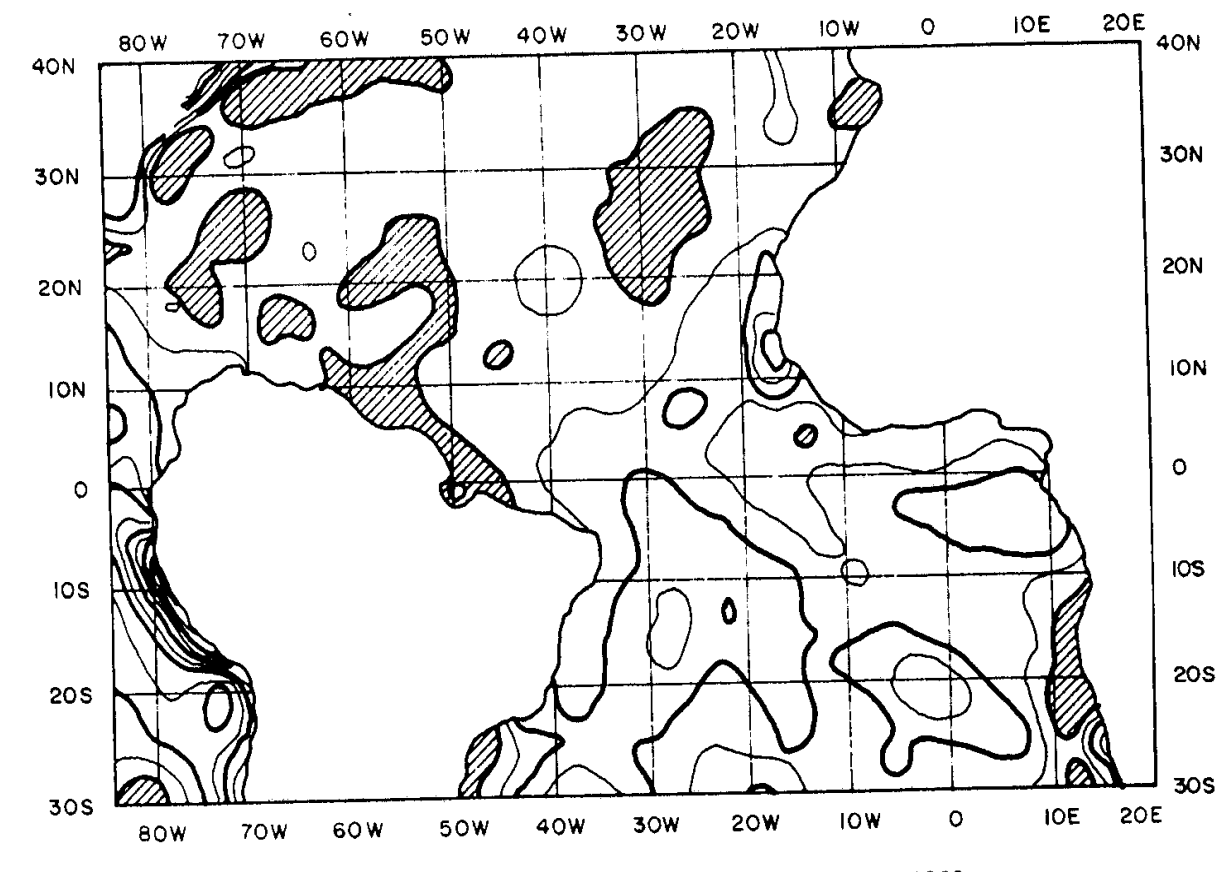

Figure 5. Same as Figure 4 except for February 1983 


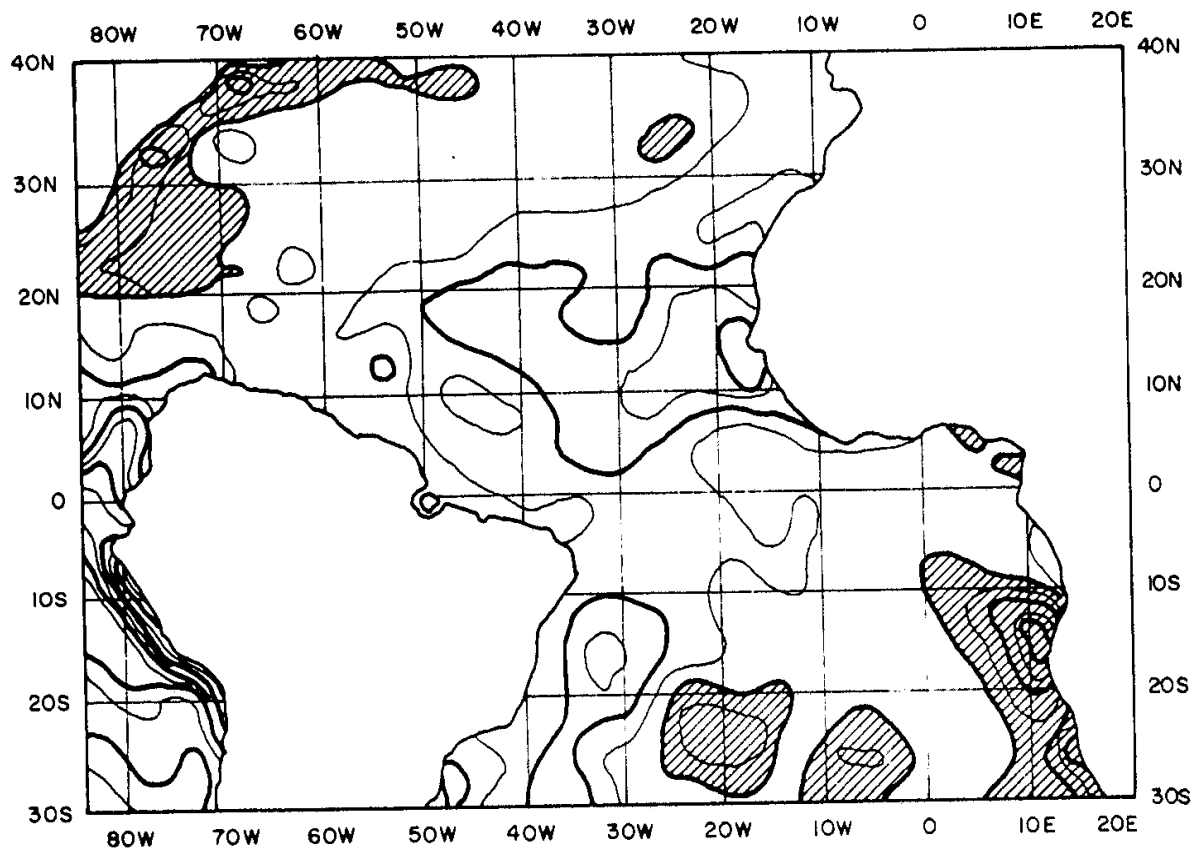

Figure 6. Same as Figure 4 except for March 1983

correlated with the March SST anomalies in NAB, and is significantly positively correlated with the November (of the previous year) SST anomaly in SAB. This result is somewhat different from the results of Moura and Shukla (1981) where the positive correlation coefficient between the rainfall and SST anomalies in SAB is higher than the negative correlation between the rainfall and SST anomalies in $\mathrm{NAB}$ for March. The negative correlations between rainfall and the difference in SST anomalies in $\mathrm{NAB}$ and $\mathrm{SAB}$ shown in column 3 are consistent. The March correlations obtained by Moura and Shukla taking rainfall of just two stations into consideration are much higher than the corresponding values given in Table I, perhaps because the values calculated in the present study are representative of northern NE Brazil as a whole.

The correlations between the SST anomalies in NAB and SAB are insignificant, except perhaps in March. However, the consistency of the negative sign (column 4, Table II) may indicate a weak association between warmer waters in $\mathrm{NAB}$ and colder waters in $\mathrm{SAB}$.

It can be seen from Table II that the correlations between SSTN and NDR and between SSTD and NDR increase gradually from January to March. The SST anomalies for January, February and March 1983 taken from Occanographic monthly summarics are shown, respectively, in Figures 4, 5 and 6 . The SST anomaly configuration in Figure 4 does not show a clear positive or negative anomaly in NAB and SAB. In February and March there are positive anomalies in NAB, with a value of the order of $1^{\circ} \mathrm{C}$ in March. In SAB also, only positive anomalies are seen in Figures 5 and 6 . Thus the SST anomalies of 1983 fail to show the positive and negative anomalies in NAB and SAB necessary for inferring a dry or wet rainfall season over NE Brazil. Although the small negative anomaly region off south-west Africa seen in Figure 6 is somewhat reminiscent of the pattern for the dry case (Figure 3(c) of Hastenrath and Heller, 1977), the large positive anomaly region in the south equatorial Atlantic is dissimilar. In any case the SST anomaly charts of January and February do not seem to indicate a dry rainfall season over NE Brazil. 


\section{DISCUSSION}

Observations of SST anomalies in the Atlantic for January, February and March 1983 do not clearly show the necessary configuration for a dry rainfall season over NE Brazil. Thus the possible explanation for the drought of 1983 might lie in the circulation changes that occurred in association with the strong El Niño/SO event of 1983. Correlations shown in Table I also suggest the importance of the SO.

Detailed discussions of the changes in the global circulations associated with El Niño during December 1982, January and February 1983 (DJF) and March, April and May 1983 (MAM) are given, respectively, by Quiroz (1983) and Chen (1983). Circulation anomalies over NE Brazil relevant for the present discussion can be inferred from these articles. Stream function anomalies at $200 \mathrm{mb}$ for both DJF (Figure 10(a) of Quiroz, 1983) and MAM (Figure 11 of Chen, 1983) show anomalous cyclonic circulation over NE Brazil (note that cyclonic stream function circulations are shown as highs in the Southern Hemisphere). At the $850 \mathrm{mb}$ level, anticyclonic anomalous circulation is seen over NE Brazil (Figure 7 of Chen, 1983). The cyclonic circulation in the upper levels over NE Brazil was noted in earlier studies (e.g. Virji, 1981) and is associated with sinking motion leading to dry conditions. This cyclonic circulation was anomalously strong during DJF and MAM of 1983; thus provoking a drought. It is not, however elear how the anomalous circulation was connected to El Niño/SO.

The effect of the SST anomalies in the SO on the global circulation has been studied using general circulation models. Julian and Chervin (1978) conducted experiments with warm SST anomalies over the eastern Pacific, starting from January initial conditions, Keshavamurty (1982) studied the effects of warm SST anomalies in the equatorial Pacific during the northern summer (JJA). Sea level pressure anomalies given in Figure 8 of Julian and Cherrin (1978) show positive anomalies over NE Brazil, indicating unfavourable conditions for rainfall. Rainfall anomalies given in Figure 4(b) of Keshavamurty (1982) show negative anomalies over NE Brazil. In spite of the acknowledged difficulties of the general circulation models, these results suggest the possible role of El-Niño/SO in the droughts of NE Brazil.

\section{SUMMARY AND CONCLUDING REMARKS}

The year 1983 was very anomalous. This year has been a strong El Niño year. The SO index reached an unprecedented value of 3.5 standard deviations below normal (Quiroz, 1983). El Niño/SO seems to have a profound influence on the climate of the South American Continent. NE Brazil experienced a severe drought.

Bjerknes (1966) suggested that more than normal SST in the eastern equatorial Pacific noted during the negative phase of the SO leads to stronger regional Hadley circulation which supports a stronger subtropical jet. This increased zonal flow carries the frontal systems rapidly into the South Atlantic before they penetrate NE Brazil with the effect the rainfall over NE Brazil is reduced (Kousky et al., 1984). Another effect of El Niño is to modify the normal Walker circulation cell over the region. In normal years the Walker circulation has two cells on equatorial Latin America and adjoining oceans, with a common rising limb over the western Amazon and with subsiding limbs over the far eastern Pacific and the mid Atlantic (Stoeckenius, 1981). During an intense El Niño year, such as 1983, the Walker circulation intensifies and perhaps shifts to the west with a strong rising limb over the eastern Pacific and with subsidence over the Brazilian coast or even over NE Brazil. The anomalous cyclonic circulation at $200 \mathrm{mb}$ over NE Brazil, noted in the previous section, is also suggestive of sinking motion. This sinking motion inhibits precipitation. The positive correlation between the SO index and NE Brazil rainfall given in Table $I$ is consistent with these explanations. During January, February and March 1983 we find that the difference between SST anomalies in the tropical North Atlantic and the tropical South Atlantic is negligible and therefore the east-west circulation effects seem to be more important than those of the meridional circulation.

Droughts in NE Brazil seem to be a combined effect of many physical processes, which vary from regional to global scale. In individual years some of these might manifest themselves, whereas the 
others do not, or even contribute in the opposite sense. Therefore, it is necessary to monitor all parameters which are known to be important for reliable forecasting of seasonal rainfall in this region.

\section{ACKNOWLEDGEMENTS}

Thanks are due to Drs A. D. Moura and F. C. Almeida for their keen interest in the present study and to Suleil A. F. V. Camargo Pinto for typing the manuscript.

\section{REFERENCES}

Bierknes, J. 1966. 'A possible response of the atmospheric Hadley circulation to the equatorial anomalies of ocean temperature', Tellus, 18, 820 .

Bunker, A. 1976. 'Computations of surface energy flux and annual air sea interaction cycles of the North Atlantic ocean', Mon. Wea. Rev., 104, 1122

Caviedes, C. N. 1973. 'Secas and El Niño: two simultaneous climatological hazards in South America', Proc. Amer. Geogr., 5, 44.

Chen, W. Y. 1983. 'The climate of spring 1983-a season with persistent global anomalies associated with El Niño', Mon. Wea. Rev., 111, 2371.

Chu, P. S. 1983. 'Diagnostic studies of rainfall anomalies in northeast Brazil', Mon. Wea. Rev.. 111, 1655.

Hastenrath, S. and Heller, L. 1977. 'Dynamics of climatic hazards in northeast Brazil', Quart. J. R. Met. Soc.. 103, 77.

Hastenrath, S., Wu, M. C. and Chu, P. S., 1984. 'Towards the monitoring and prediction of northeast Brazil droughts'. Quart. J R. Met. Soc., 110, 411 .

Julian, P. R. and Chervin, R. M. 1978. 'A study of the southern oscillation and Walker circulation phenomenon', Mon. Wea Rev., 106, 1433 .

Keshavamurty, R. N. 1982. 'Response of the atmosphere to sea surface temperature anomalies over the equatorial Pacific and the teleconnections of the southern oscillation', J. Atmos. Sci., 39, 1241.

Kidson, J. W. 1975. 'Tropical eigenvector analysis and the southern oscillation', Mon. Wea. Rev., 103, 187

Kousky, V. E. 1979. 'Frontal influence on Northeast Brazil', Mon. Wea. Rev., 107, 1140.

Kousky, V. E. and Chu, P. S. 1978 . Fluctuations in annual rainfall for northeast Brazil', J. Meteor Soc. Japan, 56, 457.

Kousky, V. E, Kagano, M. T. and Cavalcant, I. F. A, 1984. 'A review of the southern oscillation: oceanic-atmespheric circulation changes and related rainfall anomalies', "Tellus, 36 A, 490.

Marques, V. S., Rao, V. B. and Molion, L. C. B. 1983 . 'Interannual and seasonal variations th the structure and energetics of the atmosphere over Northeast Brazil', Tellus, 35A, 136

Moura, A. D. and Shukla, J. 1981. 'On the dynamics of droughts in northeast Brazil. Observations, theory and numerical experiments with a general circulation model', J. Atmos. Sci., 38, 2653.

Namias, J. 1972. 'Influence of Northern Hemisphere general circulation on droughts in northeast Brazil', Tellus, $24,336$.

Quiroz, R. S. 1983. "The climate of the "El Niño" winter of 1982-1983. A season of extraordinary climate anomalies', Mon. Wea. Rev., 11, 1985.

Ramos, R P. L. 1975. 'Precipitation characteristics in the northeast Brazil dry region', J. Geophys. Res., $80,1665$.

Rasmusson, E. M. and Carpenter. H. 1982. 'Variations in tropical sea surface temperature and surface wind fields associated with the southern oscillation/El Niño, Mon. Wea. Rev., 110, 354

Rasmusson, E. M. and Waliace, J. M. 1983. 'Meteorological aspects of the El Nino/southern oscillation'. Science, 22, 1195.

Servain, J., Picaut, J. and Merle, J. 1984. 'Compilation of sea surface temperature data for the Tropical Atlantic', Laboratoire d'oceanographie physique. Brest, France (unpublished charts).

Stoeckenius, T. 1981. 'Interannual variations of tropical precipitation patterns', Mon. Wea. Rev., $109,1233$.

Strang, D. M. G. 1972. 'Climatological analysis of rainfall normals in Northeast Brazil', Pap. no. IAE-M O2/72, (Available from Centro Técnico Aeroespacial, 12200, São José dos Campos, São Paulo, Brazil).

Virji, H. 1981. 'A preliminary study of summertime tropospheric circulation patterns over South America estimated from cloud winds', Mon. Wea. Rev., 109, 599.

Walker, G. T. 1928. 'Ceará (Brazil) famines and the general air movement', Beitr. Phys. Frain. Atmos., $14,88$. 